\title{
CURRENT CHALLENGES IN PHYSICAL AND HEALTH EDUCATION IN POLISH SCHOOL
}

In today's world, the problem of protecting human health is becoming of longlife value. This underlines the importance of the proper organization of physical education at schools, because physical education aims to preserve and strengthen the health of the young generation and its continuation later in life [5, c. 8].

Physical education and sport are components of broadly understood physical culture. In modern Polish society, physical culture is an element of a healthy lifestyle. However, it should be noted that the Polish division of forms of participation in physical culture is as follows: physical education, sport, recreation, medical rehabilitation and tourism. In the Ukrainian definition, all this is hidden in the broader concept of the term physical education. Many people lead a healthy lifestyle and play sports. As people do regular exercise walking, cycling, rollerblading, running, swimming - they care for their body, a slim figure and well-being. A healthy lifestyle is based on several basic factors: proper diet, physical activity, avoidance of harmful factors, ability to rest and the right approach to life. Physical culture has a great impact on our health and prevents many diseases. Sport reduces the risk of developing cancer and improves the functioning of the immune system, prevents bacterial and viral infections and improves the cardiovascular system. Physical culture is an important and the most effective way to reduce tension caused by stress, and also physical activity improves self-esteem.

Physical culture has been proven to have a major impact on our health and prevent many diseases, including sports that reduce the risk of cancer and improve the immune system, prevent bacterial and viral infections, and improve the cardiovascular system.

Physical education, in the ideas of the most famous Polish specialists in the field - an important and most effective way to reduce stress-induced stress, and in addition, physical activity improves self-esteem, in particular, emotional and self-esteem.

The article presents the authors' hypotheses regarding the modernization of the physical education system in general, and the optimization of teaching the school subject "physical education" in particular. Some empirical reasons are given for optimism about using these assumptions.

Emphasis is placed on the need for the use of sports and sports exercises in organizing recreation and leisure for adults and children. The negative dynamics of the scale of physical education as a compulsory part of children's education in schools and out-of-school educational institutions have been explored.

Key words: physical education, school education, sports, recreation, leisure, health, physical education in Poland.

\section{Physical education as a school subject}

Physical education is an intentional and conscious action focused on shaping attitudes. It is the subject that forms not only physical condition and shape of the body, through exercises and various activities performed during classes, but also equips children and adolescents with knowledge on how to care for the health of the body and the importance of hygiene. Also, it teaches the right attitude to the body, as well as encourages an active and healthy way of spending free time. During physical activity at school, students acquire the ability to organize and spend time with the greatest benefit for both physical and mental health. Physical education is a subject that actively accompanies the youth throughout the entire period of education. When the authors recall the school years, and more specifically elementary school, the image of children dressed in white T-shirts and black shorts that bravely warmed up running around the field, regardless of the weather, is visible [5, c. 8]. It was a time when dismissals from classes were rare, only in specific and exceptional situations. Gymnastics, goat jumping, running and volleyball tournaments were commonplace. The period of middle school and high school was the most pleasant period of physical education. The variety of physical activities, discussions about health education, or well-equipped facilities meant that the so-called PT took a new, fresher and more contemporary dimension. Despite the diversity and the breath of freshness, layoffs began to appear more and more often among girls. What was the reason? Maybe the greater freedom that students got, or perhaps the lack of awareness of the effects of lack of physical activity. Physical 
education is a subject that you like or dislike. However, sometimes it is worth thinking about what effects this lack of physical activity can have. Sport and healthy lifestyle some time ago entered the "trends" in life. However, despite the so-called "Fashion for sport", actions promoting a healthy lifestyle, or modernizing and making the curriculum more attractive, schools are currently facing the problem of avoiding physical education, which does not help obesity and overweight visible among children. The subject of the work focuses on presenting the current state of physical education in modern developed schools with an emphasis on health education.

Contemporary physical education at schools

Times are changing, bringing about new reforms, new infrastructure and cutting-edge technological and scientific achievements. And the arising question is: Do they bring only benefits? Definitely not. Living today, we have to deal with many problems and side effects of our activities on a daily basis. It is important that we should be able to cater for the needs of children throughout this confusion. For children to develop properly, it is necessary to take into account their natural need for physical activity, which leads to understanding and realizing what an important element of education physical activity is. Physical education has many important functions, among which are educational, developmental and health functions. Its main goal is to support the proper development of the child and to shape the habits of physical activity along with concern for health throughout the child's life. It is known that over time, expectations for newer standards for physical education are rising, bringing high results in the future, which will result in healthy lifestyle habits. Current physical education, in addition to fitness preparation, is particularly guided by healthy preparation. The main function of health education is to prepare the child to make health-friendly choices in life $[10$, c. 10]. The new core curriculum at schools is trying to implement a personalistic concept of education, as well as healthoriented fitness. Elementary school students carry out classes in the form of lessons with the possibility to choose activities such as sports, recreation and health, dance or active tourism. The new core curriculum shows a large variety and the ability to choose classes according to the child's interests. As part of the elective classes, content implementation is optional and should go beyond the core curriculum. Physical education classes are conducted by educated teachers who are able or at least should be able to inspire the children to love sport and take care of their health. Depending on the institution, teachers during the classes have the option of using newer, but also older sports facilities located near the school [10, c. 11]. The question remains, how does all this relate to reality? Is the school equipped with new sports facilities in the fullest? Do teachers inspire students with their creativity and energy? The authors' experience shows that not everything works as it should. Given the financial possibilities or funds allocated for the development of schools, currently not every institution has the opportunity and access to modern sports facilities. Many facilities still do not have even a gym or newer equipment. However, the fact is a visible increase in the number of sports halls and modern sports fields funded by the state or private businesses. In the years 2005-2012, the infrastructure of sports facilities improved significantly. The number of sports halls and gyms increased by $78 \%$ (sports halls) and by $156 \%$ (gyms). When it comes to sports fields, an increase of $81 \%$ was recorded [13, c. 42].

One of the many problems of the proper functioning of physical education today is a teacher burnout that is becoming more frequent. Constant changes in education, reforms, regulations, bureaucracy, salary dissatisfaction, lack of respect from students are just a few factors affecting burnout and fatigue. The teaching profession is associated with daily interpersonal contacts. Every day it is required from teachers that they do not only convey knowledge, shape attitudes but also be emotionally involved, which is often a burden on the psyche.

According to the research carried out by D. Umiastowska, teacher burnout is often caused by the wrong attitude of the management towards the teacher, treating physical education as a subject that is worse than others, and poor working conditions [8, c. 147-155]. Due to professional burnout in a growing number of schools, there is a lack of creative teachers who are full of energy and who introduce diversity in classes. Currently, teachers need a lot of support from society, which will give them motivation and hope for a better future.

In the new core curriculum for primary school, the requirements for conducting physical education classes relate to four thematic blocks. The first guideline is the block on development and physical fitness. Here, the teacher diagnoses and interprets the child's physical fitness. The teacher must not set the student's fitness as a criterion for the grade in the subject. The difference between diagnosis and assessment appears in this block. The second thematic block is physical activity, which includes content about individual and team recreation and sports forms. The content has been enriched with modern forms of movement and activity from other European countries. Modern technology is also used here to observe and plan physical activity. The third thematic block covers safety in physical activity, and the last block focuses on health education [10, c. 18]. In addition, it strengthens the importance of an active and healthy lifestyle. Today's times and the core curriculum require conducting sports activities whenever possible in the sports hall, gym or on the school playground. It is important that children, at every opportunity, should be able to enjoy outdoor activities, even in the autumn and winter. The fact is that going outside in the winter will probably encounter reluctance on the part of the group, 
but the environment and fresh air will bring more benefits than classes in a stuffy school building. The current curriculum requires, wherever possible, the provision of newer sports equipment from which children will have the opportunity to acquire skills or improve them. Besides, the school should educate on the health background, integrating physical education with biology, knowledge about society or education for safety. Combining these items will allow children to learn more about many health topics. During such classes, students who are exempt from physical education may actively participate, which is an additional advantage. Currently, schools have to face the so-called plague of exemptions from physical education classes [10, c. 18]. In particular, this applies to girls during puberty. There are many reasons, starting with the serious ones, which may be the inability to attend classes due to illness, ending with trivial ones, which are often the result of laziness and marginalization of this subject. Education and resourcefulness in planning one's professional career are responsible for the success of many young people. By following this path, students themselves create their system of subject values in school, which often makes physical education a trivial, unsuitable, and sometimes even unnecessary subject. In fact, sport and a healthy lifestyle have become "fashionable", however, the problem of marginalization of this subject still exists in schools. The matter is that, sometimes, from parents or teachers of other subjects in schools, children may hear that Physical Culture does not contribute much to the intellectual development of the student, which further diminishes the value of this subject [9, c. 24]. The fact that there is visible overweight and obesity among students due to low physical fitness does not help here. You can promote a healthy lifestyle, encourage various sports activities, constantly talk about the effects of poor nutrition or inactivity, but it's easy to argue and notice that the human mind is what it is and will not change soon.

\section{Sport as recreation}

Family sports are most often practised during weekends and holidays when finding and organizing free time together is easier. Families who practice sports disciplines regularly participate in various types of physical activities, such as gym, gymnastics, running together, tennis, playing ball, swimming, cycling, long walks, roller skating, ping-pong, dance. Physical culture in the family brings many values that do not only promote healthy leisure time but also provide us with many other positive values: it leads to an active lifestyle, develops a passion for physical effort, is a model for children to follow the pattern of a healthy lifestyle, strengthens and deepens family ties. Through joint sports activities, we educate children in mutual learning and encourage them to develop their interests and deepen the sports skills of all family members.

Urszula Parnicka believes that social changes associated with life in global reality cause changes in lifestyle. The importance of caring for health increases. Tourism, ecological education and physical activity play an important role in this respect. According to the analyzed author, the family plays a fundamental role in education for recreation in early childhood. It is because "the first socialization and educational environment that introduces a child to the world of physical games, teaches basic sports skills through games and physical games" [4]. Learning basic sports skills can be, e.g. swimming lessons - a small child is taught swimming by his parents. Parnicka lists several functions that sport activity fulfils in the family: involves into an active lifestyle, awakens the passion for physical exertion, improves the health and sports skills of all family members, carries educational values, shaping the personality of the child. The author points out that the greatest benefit of physical activity in the family is its consolidation. Sport strengthens family ties, integrates, allows you to spend your free time healthy with your family, which is very important in today's reality.

\section{The problem of avoiding physical education}

As mentioned above, the $21^{\text {st }}$ century faces the challenge of childhood obesity, which is largely associated with physical inactivity and poor diet. Just walk down the school corridor during the inter-lesson break and notice what children eat for lunch. Chips, bars, crisps, and all this with a sweetened drink. Besides, lack of physical activity, avoidance of physical education, and suddenly the problem of the $21^{\text {st }}$ century emerges. Obesity and overweight among children of the modern generation have become a global health problem. Epidemiological studies show the urgency of the problem, which is the progressive lowering of the age threshold of overweight people, especially among children who are in the puberty period. Currently, health education with a focus on preventive medicine is becoming a priority at schools. A child aged $5-17$ should spend at least 60 minutes a day on moderate or intense physical activity. Research conducted by HBSC in Poland in 2010 showed that only $27.3 \%$ of $11-12$-yearolds reached the recommended level of activity. Among older children, the level of his physical activity decreased with age [12, c. 184]. Physical activity is necessary for the proper psychophysical development of the child. Lack of this activity is one of the main causes of civilization diseases. In the era of computer games and smartphones, children stop moving, forgetting what physical activity is. According to studies carried out by school boards or local governments, physical education is usually the only form of activity, and the percentage of students who do not exercise at all during classes is significant. In 2007, in Gdańsk, there were $10 \%$ of students with permanent dismissal in upper secondary school, while when it came to individual dismissals, there was an average of $40 \%$ among girls, where the problem is bigger. The report of the Supreme Audit Office, after a week's observation at 15 primary schools, 18 junior high schools and 11 high schools, 
noted that $9.5 \%$ of students in primary education did not exercise in physical education, $12.9 \%$ in lower secondary schools and $21.8 \%$ in high schools where the problem is more serious. The most common reason for not exercising during lessons was the lack of sports outfit recorded in as much as $33.1 \%$, as well as the dismissal written by parents in $22.8 \%$ and sick leave which amounted to as much as $17.7 \%$ of dismissals [7, c. 58]. This problem did not arise in the $21^{\text {st }}$ century. The research conducted in 1974 in 170 selected primary schools showed that $4.5 \%$ of pupils had a longer layoff than 2 months (3\% in primary schools, $7 \%$ in high schools) [12, c. 184]. It is known that the result will not be the same in every school. There are schools where the attendance will be $100 \%$, but there are also schools with over $50 \%$ of those exempted from classes. Thinking back to our middle school and high school, we remember the phenomenon of the problem of avoiding physical education. The most frequent layoffs occurred among girls and in as much as $50 \%$ compared to those exercising, where the reasons were very trivial, even absurd. In this case, you should think about what is the reason and cause. This is a problem that should not be underestimated. Research carried out by P. Batorańska shows that girls are most often exempted by parents and doctors, and the most common causes are malaise, indisposition, colds, but also limb injuries, back problems, and joint problems. Also, it is worth emphasizing that in almost every group during physical education classes there are exemptions written by parents, without giving any reason for the student's indisposition. Partial dismissals issued by doctors are very common. In this case, the student is exempt from certain physical activities such as turns, runs, etc. Exemptions in most cases do not represent specific types of exercises, competition or movement tasks, but are described in a general way [1]. The most puzzling reasons for dismissals are those written by parents. What can be understood by the reason: "malaise" or by not giving any reason? One can speculate a lot, but only the student knows the truth. It is clear that the student or parent will not give the reason for dismissal, which may be ordinary laziness, or simply a simple dislike of the teacher or shame. However, remembering our experiences from the high school period, we can clearly state that laziness, reluctance to physical activity, fear of sweat, or shame of peers are one of the many reasons for dismissal "for no reason". Many school locker rooms do not have showers to refresh after physical education lessons. However, when the cloakroom has showers, there is a problem of lack of habit and laziness to take advantage of this opportunity. Besides, it is worth noting that girls during adolescence strongly take the opinions of their peers. This becomes a sufficient reason for the unwillingness to participate in physical activity due to their own "imperfections". In addition to that, it is also worth considering another reason for not participating in physical education classes, namely the lack of a suitable sports outfit. Are students really so forgetful that they can, on average, every week or two weeks forget their clothes? Or is it just a simple excuse because of laziness? The physical activity aims to improve overall fitness. Taken during childhood or adolescence brings positive results in adulthood. The fact that the number of redundancies is increasing at a rapid pace is worrying. It makes us think about what the reason is and what we can do to change it. With age, the number of dismissals issued by parents for no reason increases, and girls use them most often. The fast pace of life, the development of civilization, and newer technologies bring many benefits, but it is worth considering whether, on the other hand, it does not pull the young generation away from physical activity. More and more often overworked parents do not notice the scale of the problem, which may be inactivity, without thinking about the dismissal. It is them who should first start thinking about unreasonably writing out a dismissal, so as not to hurt their child.

\section{Health Education}

According to the World Health Organization, "health is a state of complete, well-being (physical, mental and social), and individuals or groups must be able to identify and pursue their aspirations, meet their needs, and change or cope with the environment. Therefore, health is perceived as a life resource and not a life purpose. Health is a positive concept, including personal and social resources and physical capabilities, and not just the lack of objectively existing illness or disability" [6]. Health education in the school of developed modern societies plays a very important role. It has been included in the preamble of the new core curriculum for primary and secondary school. The school is not only obliged to provide students with adequate knowledge about health, but also should take measures to maintain and strengthen the students' health. The educational institution for children is recognized as one of the most important environments where the child has the opportunity to acquire health knowledge and form attitudes preparing for a healthy lifestyle in the future. However, the teacher's task is to inspire and involve the child in healthy nutrition, lifestyle and health matters, which will enable the young generation to effectively deepen their knowledge on this subject [11, c. 7]. Due to the problem associated with poor eating habits, the increasing number of exemptions from physical education, and obesity and overweight spreading among the younger generation, schools actively began to join in the promotion of health, which is a new concept and strategy of actions aimed at health. Health promotion aims to shape optimal living conditions for maintaining good health and mediation between people and the environment regarding individual choices as well as social activities. Correct actions should lead to the effect of increasing responsibility for health in the future [11, c. 14]. Currently, health education in schools is based on three pillars. The first pillar focuses on 
the transfer of knowledge on health, disease and safety. The task of the second pillar is to shape the ability to use the acquired knowledge in everyday situations. The last pillar is based on the formation of pro-health attitudes. It is worth noting that the formation of attitudes is a long-term process and depends on environmental factors such as family, school or peer. The formation of a child's attitude is facilitated by the period of school education, which is the basis of human life. Therefore, the development of awareness in the field of caring for health and mobilization of the child to deal with health threats is even necessary for the proper growth of a young person [11, c. 14]. Not only Poland is trying to introduce effective solutions in the field of health education in school life. In 1992, under the agreement of the World Health Organization, the Council of Europe and the European Commission, the European School Network for Health in Europe was established, which covers 32 countries, including Poland. The United States, as well as Austria and the Czech Republic, introduced a health program similar to the program of Schools Promoting Health in Europe. Denmark, on the other hand, has developed a democratic and environmental health education program and it has influenced the emergence of the European Network of Health Promoting Schools. Besides, Ireland has implemented a social, personal and health education program, which is supported, coordinated and supervised by a state institution specially established for this purpose. Finland, for instance, introduced the school subject called "Health" with the obligatory final exam [3, c. 209-210]. The new reform has outlined a new model of education that has changed from reproductive to active. School facilities have begun to implement education that should be more child-friendly and adapted to current times. It is education open to modern concepts of pro-health education and upbringing. An important point of the new reform is also the changing role of the teacher and student, who are currently treated more subjectively, which imposes maintaining good and proper relations between them based on mutual recognition and respect. The use of active methods during the course of education allows students to use the acquired knowledge in practice [11, c. 33]. Certainly, the intentions and the plan currently implemented in education is good, but it is worth considering whether it will bring the assumed effects. Today's children belong to a bored smartphone generation, and it takes a lot of effort and creativity to interest them. The modern world is facing such a challenge.

\section{Conclusions}

Currently, the world has to face many problems. The fast lifestyle, easy access to all products and lack of time for oneself and children cause obesity and overweight, which the young generation frequently suffers from. By introducing new reforms and regulations, education tries to prevent this phenomenon. Anew curriculum that should encourage students to participate in physical education, teacher training, modernization and construction of new sports facilities, expanding the scope of health education, promoting a healthy lifestyle, or health programs and projects are just some of the activities aimed at developing awareness and health responsibility. Everything seems to be an ideal plan, but reality shows that most of the unhealthy habits of children are taken from the home. School can contribute a lot to a child's life, help him or her develop, however, if parents do not cooperate with the institution, school activities will bring less fruitful effects. Physical education is an important and necessary subject for developing healthy lifestyle habits. Activity during classes and the right amount of movement during the school period have a big impact on the maturing process. Unfortunately, the problem of exemptions from physical education is still a highscale problem that should be resolved as soon as possible. Lack of movement at such a young age leads to serious illnesses, loss of health or muscle wasting. It is also worth noting that schoolchildren do not have sufficient awareness of the effects of not participating in lessons. In this regard, the responsibility falls on parents and teachers, whose task is to encourage physical activity, as well as instil appropriate health habits. The purpose of the new core curriculum is to introduce a modern and student-friendly education model for health education. The plan is good, but the reality in schools raises many questions. It is worth noting that each school, despite the same curriculum, differs from each other. There are differences between teachers, students, the management, the facilities, or just locations. Not every school can implement the new health education model appropriately. Undoubtedly, physical education and health education try to meet the needs. However, deficiencies still need to be addressed in the system and organization of schools. Physical education in schools raises a lot of controversies, which is why the European Commission decided to draw up a report that presents the strengths and weaknesses of physical education. The conclusions were as follows: physical education at primary and lower secondary levels is implemented as a compulsory subject. All curricula in developed countries contain elements of the child's physical, personal, social and health development.

\section{References:}

1. BatorzyńskaP., Frekwencja orazgłówne przyczyny zwolnień uczniów w lekcjach wychowania fizycznego. URL: https://depot.ceon.pl/bitstream/ handle/123456789/16818/Batorzy\%C5\%84ska. pdf?sequence=1\&isAllowed=y] (pobrano: 12.12.2019).

2. Komisja Europejska /EACEA/Eurydice, 2013. Physical Education and Sport at School in Europe. (Wychowanie fizyczne i sport w szkołach w Europie), Raport Eurydice. Luksemburg: Urząd Publikacji Unii Europejskiej, [dostęp: 28.11.2019.]. URL: http://eurydice.org.pl/wp-content/uploads/2014/12/ PE_PL.pdf 
3. Nowak P.F. Model edukacji zdrowotnej w polskiej szkole w opiniach nauczycieli [w:] Hygeia Public Health. Opole, 2012.

4. Parnicka U. URL: http://www.vulcan.edu.pl/eid/ archiwum/2000/02/rekreacja.html (data dostępu: 26.06.2018). Akademii im. Jana Długosza w Częstochowie, Częstochowa, 2015.

5. Skalski D., Koncepcje edukacji fizycznej w krajach Unii Europejskiej: historia i współczesność, [wydanie w języku polskim - drugie, zmienione, pod konsultacją naukową prof. dr hab. Oksany Zabolotnej], Wydawnictwo Uczelniane Umańskiego Państwowego Uniwersytetu Pedagogicznego im. Pawła Tyczyny w Umaniu. Umań, 2019.

6. Światowa Organizacja Zdrowia, Zdrowie Definicja Światowej Organizacji Zdrowia (WHO). URL: https://ekaloria.pl/zdrowie/, (pobrano: 12.12.2019).

7. Tomik R., Bursy B. Unikanie ćwiczeń ruchowych podczas lekcji wychowania fizycznego. Problem czy zjawisko marginalne w szkołach podstawowych [w:] Rozprawy Naukowe Akademii Wychowania Fizycznego we Wrocławiu. Wrocław, 2013.
8. Umiastowska D., Gdaniec A. Zjawisko wypalenia zawodowego wśród nauczycieli wychowania fizycznego. Częstochowa, 2016.

9. Urniaż J., Jurgielewicz-Urniaż M. Rozwój szkolnegowychowania fizycznego na przestrzeni dziejów w Polsce a współczesny problem jego unikania, Prace Naukowe Akademii im. Jana Długosza w Częstochowie. Częstochowa, 2015.

10. Wieczorek M. Podstawa programowa kształcenia ogólnego z komentarzem; Szkoła podstawowa, Wychowanie fizyczne, ORE. Warszawa, 2018.

11. Wolny B., Edukacja zdrowotna w szkole. Poradnik dla dyrektorów szkół i nauczycieli, Ośrodek Rozwoju i Edukacji. Warszawa, 2019.

12. Woynarowska B., Mazur J., Oblacińska A. Uczestnictwo uczniów w lekcjach wychowania fizycznego w szkołach w Polsce [w:] Hygeia Public Health. Warszawa, 2015.

13.Zalewski-Elgierd A. Uwarunkowania edukacji zdrowotnej Wychowanie fizyczne w szkołach, NIK. Warszawa, 2014.

\section{Скальські Д., Заболотна О. Сучасні завдання 3 фізичного виховання i здоров'я в основі польської школи \\ У статті висвітлено актуальну проблему фізичного виховання та оздоровлення дітей у поль-} ських загальноосвітніх школах. Показано, що в сучасному світі проблема охорони здоров'я людини стає все більш важливою, починаючи з дитинства до дорослого життя. Підкреслено важливість правильної організації фрізичного виховання в школах, оскільки фрізичне виховання має на меті збереження та зміцнення здоров'я молодого покоління та його продовження в подальшому житті.

Наголошено, що фрізичне виховання та спорт є складниками масової фрізичної культури. У сучасному польському суспільстві фрізична культура є елементом здорового способу життя. Зазначено, що польський розподіл форм участі у фізичній культурі такий: фрізичне виховання, спорт, відпочинок, медична реабілітація та туризм.

В українському визначенні все це приховано в більш широкій концепції терміна «фрізичне виховання». Показано, що у Польщі багато людей ведуть здоровий спосіб життя та займаються спортом, в їхній ідеї про здоровий спосіб життя одним із найважливіших фракторів є фрізичне навантаження. Доведено, що завдяки регулярним заняттям спортом та різними його підвидами: спортивною або скандинавською ходьбою, їздюю на велосипеді, катанням на роликах, бігом, плаванням польське населення піклується про своє тіло, струнку фрігуру та самопочуття.

Представлено загальну концепцію фрізичної досконалості в масовій свідомості польських шкільних педагогів та організаторів дитячого та дорослого спорту. Здоровий спосіб життя заснований на кількох основних фракторах: правильне харчування, фрізичні навантаження, уникнення шкідливих фракторів, здатність до відпочинку та правильний підхід до життя.

Доведено, що фізична культура має великий вплив на наше здоров'я та запобігає багатьом захворюванням, зокрема, спорт знижує ризик розвитку раку та покращує роботу імунної системи, запобігає бактеріальним та вірусним інфекціям, покращує серцево-судинну систему.

Фізична культура в уявленнях найбільш відомих польських фрахівців галузі - важливий і найефективніший спосіб зменшити напругу, викликану стресом, а крім того, фізичне навантаження покращує самооцінку, зокрема емоційно-оцінне ставлення до себе.

У статті представлено гіпотези авторів щодо модернізації системи фрізичного виховання взагалі та оптимізації викладання шкільного предмету «фрізичне виховання» зокрема. Представлено деякі емпіричні підстави для оптимізму щодо використання даних припущень.

Наголошено на необхідності використання спорту та спортивних вправ під час організації відпочинку та дозвілля громадян дорослого віку та дітей. Експліковано негативну динаміку щодо масштабу представленості фрізичного виховання як обов'язкової частини освіти дітей в школах та позашкільних закладах освіти.

Ключові слова: фрізичне виховання, шкільна освіта, спорт, відпочинок, дозвілля, здоров'я, фрізичне виховання в Польщі. 